\title{
Vesicular-arbuscular Mycorrhizal Peat-based Substrates Enhance Symbiosis Establishment and Growth of Three Micropropagated Species
}

\author{
H. W ang ${ }^{1}$, S. Parent ${ }^{2}$, A. G osselin ${ }^{3}$, and Y. Desjardins ${ }^{3}$ \\ Département de Phytologie, Centre de Recherche en Horticulture, Faculté des Sciences de l'Agriculture \\ et de l'Alimentation, Université Laval, Québec, PQ, Canada G1K 7P4 \\ Additional index words. micropropagation, in vitro, Gerbera, Nephrolepis, Syngonium, Glomus intraradices, Glomus \\ vesiculiferum

\begin{abstract}
Micropropagated plantlets of Gerbera jamesonii H. Bolus ex Hook. F. 'Terra Mix', Nephrolepis exaltata (L.) Schott 'Florida Ruffles', and Syngonium podophyllum Schott 'White Butterfly' were inoculated with two vesicular-arbuscular mycorrhizal (VAM) fungi, Glomus intraradices Schenck and Smith and G. vesiculiferum Gerderman and Trappe. They were potted in three peat-based media to determine the effects of mycorrhizal peat substrate on acclimatization and subsequent growth of micropropagated plantlets under greenhouse conditions. Symbiosis was established between the three ornamental species and VAM fungi within 4 to 8 weeks of culture in the greenhouse, but not during acclimatization. Mortality of Gerbera and Nephrolepis mycorrhizal plantlets was reduced at week 8 compared to the noninoculated control. A peat-based substrate low in $P$ and with good aeration improved VAM fungi spread and efficiency. Mycorrhizal substrates had a longterm benefit of increasing leaf and root dry weight of Gerbera and Nephrolepis. Mycorrhizal Gerbera plants flowered significantly faster than non-mycorrhizal plants.
\end{abstract}

Micropropagation has become an important method of propagating horticultural plants (Chu and Kurtz, 1990). Transferring micropropagated plants from tubes to ex vitro conditions is normally difficult, because they have a poorly developed cuticle (Wetzstein and Sommer, 1982), functionally impaired stomata (Lee and Wetzstein, 1988), and a poorly developed root system (Pierik, 1987). Various studies have been conducted to improve the environmental conditions either in vitro or ex vitro to reduce the stressful passage to controlled exterior conditions (Desjardins et al., 1987, 1990; Donnelly et al., 1985; Lee and Wetzstein, 1988; Vanderschaeghe and Debergh, 1987; Wetzstein and Sommer, 1982, 1983).

Vesicular-arbuscular mycorrhizal (VAM) fungi can form a symbiosis with a wide variety of plant hosts. Beneficial interactions between VAM fungi and horticultural crops have been well documented (Menge, 1983). The symbiosis stimulates growth and development of plants (Biermann and Linderman, 1983; Crews and Johnson, 1978; Plenchette et al., 1982), increases absorption of plant immobile elements (Ames et al., 1983; Mosse, 1973), increases drought tolerance (Augé et al., 1986; Bolgiano et al., 1983), and reduces disease incidence (Dehne, 1982). Moreover, colonization with VAM fungi increases uniformity and reduces mortality (Biermann and Linderman, 1983) and injury of transplants (Menge et al., 1978). However, little is known about how VAM fungi improve acclimatization and growth of micropropagated plantlets (Granger et al., 1982; Ponton et al., 1990).

The nature and properties of substrates are critical for establishment and performance of VAM fungi and micropropagated plant-

Received for publication 7 July 1992. Accepted for publication 9 Dec. 1992. Contribution CRH-53 from the Centre de recherche en horticulture. The authors acknowledge the financial support of Premier Peat-Moss Ltd. and of the Conseil des recherches en pêche et en agro-alimentaire du Québec (CORPAQ). The cost of publishing this paper was defrayed in part by the payment of page charges. Under postal regulations, this paper therefore must be hereby marked advertisement solely to indicate this fact.

${ }^{1}$ Graduate student.

${ }^{2}$ Scientist, Centre de Recherche Premier, Tourbières Premier, Rivière-du-Loup, PQ, Canada G5R 4C9.

${ }^{3}$ Professor. lets during acclimatization. Peatmoss-based substrates are commonly used in horticultural productions in containers and have a great commercial potential as acclimatization media for micropropagated ornamentals (Castle and Ferguson, 1982). Gramam and Timmer (1984) reported that high organic-matter content and available $\mathrm{P}(>20 \mathrm{mg} \mathrm{P} / \mathrm{g}$ substrate $)$ in a peat-based medium inhibited mycorrhizal colonization and limited growth response of host plants. Caron and Parent (1987) further stated that the spread and efficiency of VAM fungi as well as host plant growth could be affected by the nature of the peatmoss used. Ponton et al. (1990) suggested that a brown peat-based medium was more suitable for VAM fungi $(G$. intraradices and $G$. vesiculiferum) activity and fern (Nephrolepis exaltata) growth than a black peat-based medium. But, little has been known about the effects of different types of peat-based media on VAM activity or on micropropagated plantlet acclimatization and growth.

For these reasons, a study was undertaken 1) to determine whether the mycorrhizal fungi $G$. intraradices and $G$. vesiculiferum can establish symbioses with micropropagated plants of Gerbera, Nephrolepis, and Syngonium; 2) to evaluate the effects of different peat-based substrates (PBS) on VAM fungi establishment and VAM-inoculated peat-based media on acclimatization of micropropagated plants; and 3) to evaluate long-term benefits of VAM on growth and productivity of micropropagated ornamental plants.

\section{Materials and Methods}

Micropropagated plantlets. Three species of micropropagated ornamentals were used in the experiment: Gerbera jamesonii 'Terra Mix', Nephrolepis exaltata 'Florida Ruffles', and Syngonium podophyllum 'White Butterfly'. The explants were surface disinfested for 2 min with $70 \%$ ethanol, 30 min in 1.5\%

\footnotetext{
Abbreviations: AW, available water; BD, bulk density; GW, gravitational water; PBS, peat-based substrate; \% REC, intensity of root-length endomycorrhizae colonization; VAM, vesicular-arbuscular mycorrhizal; WCS, water content at saturation.
} 
sodium hypochlorite with $0.01 \%$ Tween-20, followed by four 5 min rinses in sterilized distilled water. The basal nutrient medium in all experiments contained Murashige and Skoog (1962) salts and vitamins (MS), 3\% sucrose, and 0.7\% Difco Bacto agar. The $\mathrm{pH}$ was adjusted to 5.7 with $0.1 \mathrm{~N} \mathrm{NaOH}$. The concentration of plant growth regulators in the medium was (in $\mu \mathrm{M}$ ) 23.2 kinetin $\left(\mathrm{N}^{6}\right.$-furfuryladenine) +2.9 IAA (indole-3-acetic acid) for Gerbera, 9.3 kinetin +0.05 NAA ( $\alpha-$ naphthaleneacetic acid) for Nephrolepis, and 13.3 BA (6-benzyladenine) + 1.6 NAA for Syngonium. The cultures were incubated at a constant $24 \pm 2 \mathrm{C}$, under a 16-h photoperiod provided by fluorescent lamps (coolwhite) supplying $48 \mu \mathrm{mol} \cdot \mathrm{s}^{-1} \cdot \mathrm{m}^{-2}$ photosynthetic photon flux (PPF). Following 6 monthly subcultures, 500 micropropagated plantlets per species were obtained for the experiments.

Substrates. The substrates used in the experiments were peatbased and were prepared by Tourbières Premier (Rivière-duLoup, Québec, Canada). Three PBS were prepared by combining $(\mathrm{v} / \mathrm{v}) 1$ vermiculite (fine grind no. 2) : 3 moss peat. Substrate 1 was a fibric-mesic sphagnum peatmoss, sifted through a 19-mm mesh sieve, with a decomposition value of $\mathrm{H} 4$ on the Von Post scale. This substrate is fine-textured and is similar to a germination medium sold commercially by the company. Substrate 2 was finely ground (5-mm) fibric sphagnum peatmoss peat, with a decomposition value of $\mathrm{H} 2$ on the Von Post scale. Substrate 3 was a fibric peatmoss peat, also with a decomposition value of $\mathrm{H} 2$. The three substrates differed in their physical and chemical characteristics (Table 1).

VAM inocula. The Glomus intraradices and G. vesiculiferum used were commercial VAM inocula produced by Centre de Recherche Premier (Rivière-du-Loup). Samples of these two Glomus species have been deposited at the National Mycology Herbarium, Ottawa, Canada, and are respectively identified with the numbers DAOM 197198 and DAOM 198531. The three substrates were inoculated with either G. intraradices or G. vesiculiferum or were not inoculated and used as controls. The substrates were not sterilized. A priori, all peat types were devoid of VAM fungi as confirmed by the absence of colonization with the noninoculated treatments. Experimental substrates were inoculated by adding a 1-liter mixture of leek (Allium ameloprasum L.) roots pieces and inoculated substrate containing spores and hyphae of the appropriate fungus to 113 liters of peat substrate. Each of the two types of noninoculated controls received the same quantity of non-mycorrhizal leek roots.

Plant acclimatization and greenhouse conditions. The experiment was conducted in a greenhouse of the Horticulture Research Center at Laval Univ. In vitro plantlets were transferred from test tubes to Cell Pack multicell containers; cell volume was $100 \mathrm{~cm}^{3}$. Plantlets were then grown under a small plastic tunnel and misted twice daily during the first 2 weeks to maintain a saturated air humidity. The inside of the tunnel was maintained at $23 \pm 1.5 \mathrm{C}$ during the day and $20 \pm 2 \mathrm{C}$ at night. Substrate hydration was

Table 1. Analysis of physical and chemical characteristics of three peatbased substrates (before culture) ${ }^{\mathbf{Z}}$

\begin{tabular}{|c|c|c|c|c|c|c|}
\hline Substrate & $\begin{array}{c}\mathrm{BD} \\
\left(\mathrm{kg} \cdot \text { liter }^{-1}\right)\end{array}$ & $\begin{array}{c}\text { WCS } \\
(\% \mathrm{v} / \mathrm{v})\end{array}$ & $\begin{array}{c}\mathrm{AW}^{\mathrm{y}} \\
(\% \mathrm{v} / \mathrm{v})\end{array}$ & $\begin{array}{c}\mathrm{GW}^{\mathrm{x}} \\
(\% \mathrm{v} / \mathrm{v})\end{array}$ & $\begin{array}{l}\mathrm{P}-\mathrm{PO}_{4} \\
(\mathrm{ppm})\end{array}$ & $\mathrm{pH}$ \\
\hline$\overline{1}$ & $0 . \overline{12}$ & 680 & 25.0 & 11.7 & 2.0 & 5.78 \\
\hline 2 & 0.05 & 1330 & 34.7 & 14.9 & 2.0 & 6.38 \\
\hline 3 & 0.06 & 1060 & 35.2 & 16.4 & 1.2 & 6.57 \\
\hline
\end{tabular}

${ }^{\mathrm{z}} \mathrm{See}$ abbreviation list on first page.

y Water tension $=0.01$ to 0.1 bars

${ }^{\mathrm{x}}$ Water tension $<0.01$ bars. maintained above $85 \%$ of full saturation. Depending on the species, plantlets were acclimatized for an additional 2 to 4 weeks by gradually reducing relative humidity $(\mathrm{RH})$ to the greenhouse level of $70 \% \mathrm{RH}$. Plantlets were then transferred to $100-$ or $125-\mathrm{mm}-$ diameter (2.3- or 2.5-liter) plastic pots containing the same substrate and placed in a greenhouse. Plants were watered as needed and fertilized weekly with $100 \mathrm{ml}$ of a solution that contained (in mg.liter $\left.{ }^{-1}\right) 480 \mathrm{MgSO}_{4} \cdot 7 \mathrm{H}_{2} \mathrm{O}, 750 \mathrm{Ca}\left(\mathrm{NO}_{3}\right)_{2} \cdot 4 \mathrm{H}_{2} \mathrm{O}, 31.410 \mathrm{~N}-$ $52 \mathrm{P}_{2} \mathrm{O}_{5}-10 \mathrm{~K}_{2} \mathrm{O}$ (Plant Products Co., Bramalea, Ont., Canada), and $55012 \mathrm{~N}-0 \mathrm{P}_{2} \mathrm{O}_{5}-44 \mathrm{~K}_{2} \mathrm{O}$ (Plant Products Co.). This nutrient solution was based on that of Long Ashton (Hewitt, 1966) and is low in $\mathrm{P}$.

Design of experiment. A randomized complete block design was used to investigate the effect of VAM and PBS on acclimatization and growth of Gerbera, Nephrolepis, and Syngonium. For each species, there were nine treatments consisting of a factorial arrangement of two VAM-inoculated treatments and a control noninoculated treatment, and three PBS. There were 36 plants per treatment randomly distributed to three blocks. Each experimental unit consisted of 12 plants.

Measurement and statistical analysis. The plants of each treatment in each block were harvested 4, 8, 12, and 16 weeks following inoculation to determine the percentage of root-length colonization. The root system was lightly washed with running tap water. Five root segments per plant and 15 root segments per treatment were sampled, and five observation points per root segment were examined. The percentage of root segments containing hyphae, arbuscules, and vesicles were determined using the grid intercept method of Giovannetti and Mosse (1980), after clearing and staining the roots with fuschin acid according to Phillips and Hayman (1970). Microscopic examination was made under 125x magnification. The survival of plantlets was measured 4 and 8 weeks after their transfer to ex vitro conditions and inoculation with mycorrhizal substrate. Growth was measured by harvesting three plants of each treatment in each block at $4,8,12$, and 16 weeks following inoculation. Because of slow growth of Syngonium, growth measurements were taken only for Gerbera and Nephrolepis. The root system was washed of soil particles with running tap water, and above- and underground tissues were oven-dried separately for $72 \mathrm{~h}$ at $65 \mathrm{C}$ before dry weight was recorded.

The analyses of chemical and physical characteristics as well as analysis of hydrophysical properties of substrates were conducted by the Centre de Recherche Premier (Rivière-du-Loup). Nutrient concentration in substrates was determined by saturation extraction methods (SEM) (Warnche, 1986). The following substrate physical and chemical characteristics were evaluated before culture: bulk density (BD), water content at saturation (WCS), gravitational water (macroporosity) (GW) (water tension <0.01 bars), available water (water tension $=0.01$ to 0.1 bars) $(\mathrm{AW}), \mathrm{P}-\mathrm{PO}$, and $\mathrm{pH}$ (Table 1). Analyses confirmed that both fibric sphagnum peatmosses had lower bulk density and more macroporosity and available water than the fibric-mesic sphagnum peatmoss (substrate 1). Of the two fibric sphagnum peatmosses (substrates 2 and 3), substrate 3 had a higher GW and less available P. Substrate 1 had a higher BD with the least GW and AW.

An analysis of variance was performed on SAS software (SAS Institute, 1982) using a general linear model on the mean of each experimental unit. The three species were analyzed separately. No transformation was conducted on percentage data since residuals were randomly and normally distributed. The variance of the different treatments was also homogeneous. For all characteristics studied, a Duncan multiple range test $(P<0.05)$ was used to identify differences among means. 


\section{Results}

VAM fungal establishment and spread in micropropagated Gerbera, Nephrolepis, and Syngonium plantlets. VAM fungal establishment and spread were evaluated by measuring the intensity of root-length endomycorrhizae colonization (\% REC). Extramatrical mycelium coming from infected root segments were observed on the root surface 4 weeks after Gerbera and Nephrolepis plantlets were transferred to mycorrhizal substrate (Fig. 1). Infection by VAM was observed after 8 weeks for Syngonium. The percentage of colonization increased rapidly from week 8 to week 16 for Gerbera and Nephrolepis, while it remained constant and slow for Syngonium. Differences in colonization intensity between $G$. intraradices and $G$. vesiculiferum became significant after 8 weeks for Nephrolepis, while significance was observed after 12 weeks for Gerbera and Syngonium.

Throughout the experiment, all tested species were infected more by $G$. vesiculiferum than by $G$. intraradices. Although no statistical comparison was conducted between the three species with respect to their receptivity to VAM infection, Gerbera was the most infected with $61 \% \pm 2.3 \%$, followed by Nephrolepis with $41 \% \pm 2.8 \%$, and Syngonium with $13.4 \% \pm 3.6 \%$. By the end of the

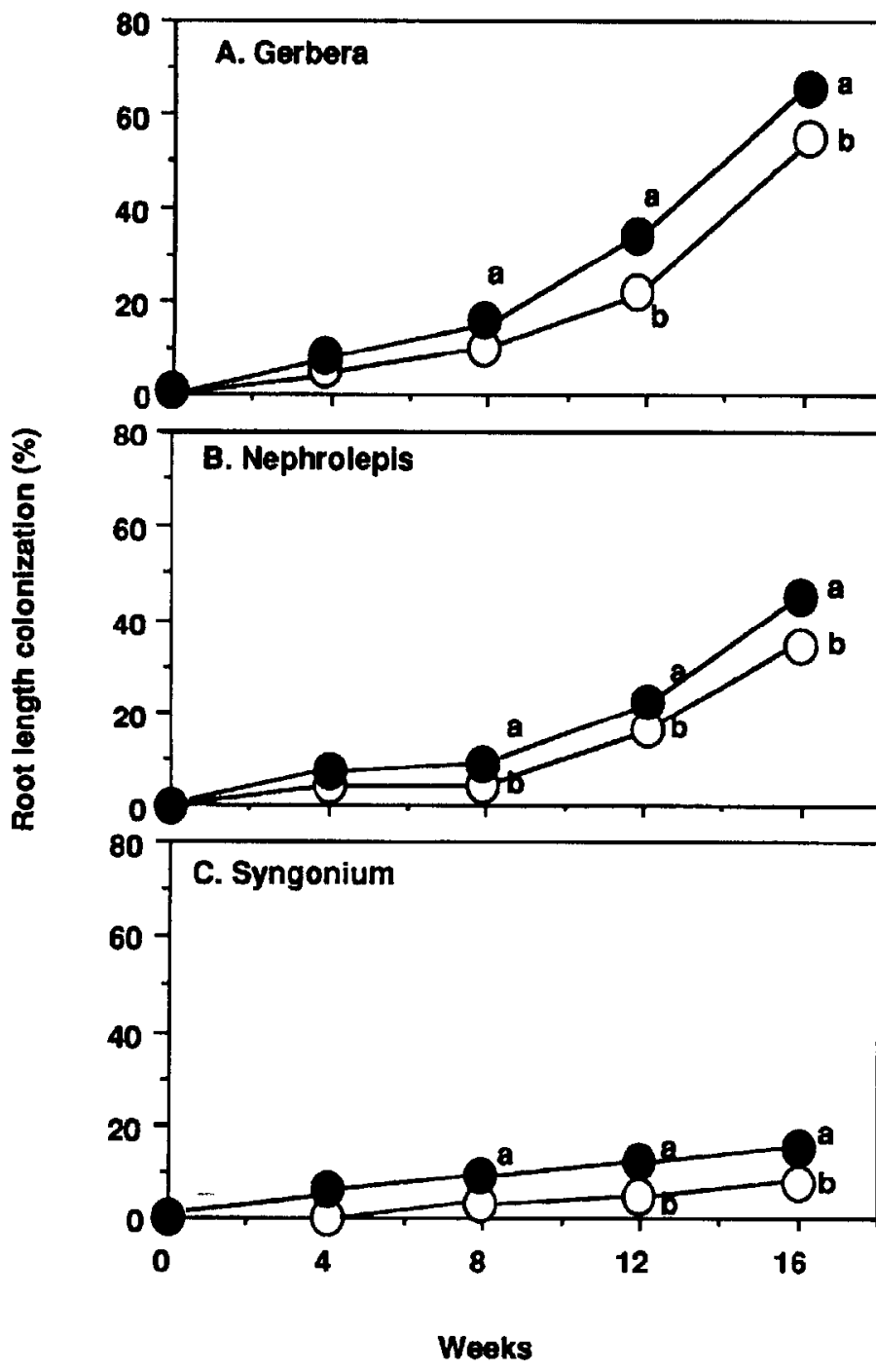

Fig. 1. Colonization intensity of Gerbera (A), Nephrolepis $(\mathbf{B})$, and Syngonium $(\mathbf{C})$, with Glomus intraradices $(O)$ and $G$. vesiculiferum $(O)$ at $4,8,12$, and 16 weeks after inoculation. Mean separation by $t$ test $(P \leq 0.05)$. experiment, $G$. vesiculiferum and $G$. intraradices had heavily infected the roots of Gerbera (67\% and 55\% REC, respectively) (Fig. 1A), moderately infected the roots of Nephrolepis (36\% and $47 \%$, respectively) (Fig. 1B), and weakly infected the roots of Syngonium (27\% and $11 \%$, respectively) (Fig. 1C).

Mycelium morphology within cortical cells also was dependent on the host plant. There was more arbuscule than vesicle development in Nephrolepis and more vesicle than arbuscule development in Gerbera. Only vesicles were apparent in Syngonium.

Effect of three PBS on symbiosis establishment. The different substrates had a strong influence on VAM symbiont establishment (Fig. 2). For the three species and the four sampling dates, there was no interaction between substrate type and VAM species. A higher colonization rate was obtained in the fibric PBS (substrates 2 and 3) than in the fibric-mesic PBS (substrate 1) at every sampling date for Nephrolepis and at 12 weeks for the others. A mycorrhizal infection was obtained after only 4 weeks in fibric PBS, while it was observed after 8 weeks within fibric-mesic PBS. In general, substrate 3 allowed for the best VAM colonization regardless of plant species.

Effects of VAM fungi and PBS on plantlet survival. The plantlet survival rate was determined after 4 and 8 weeks following transfer

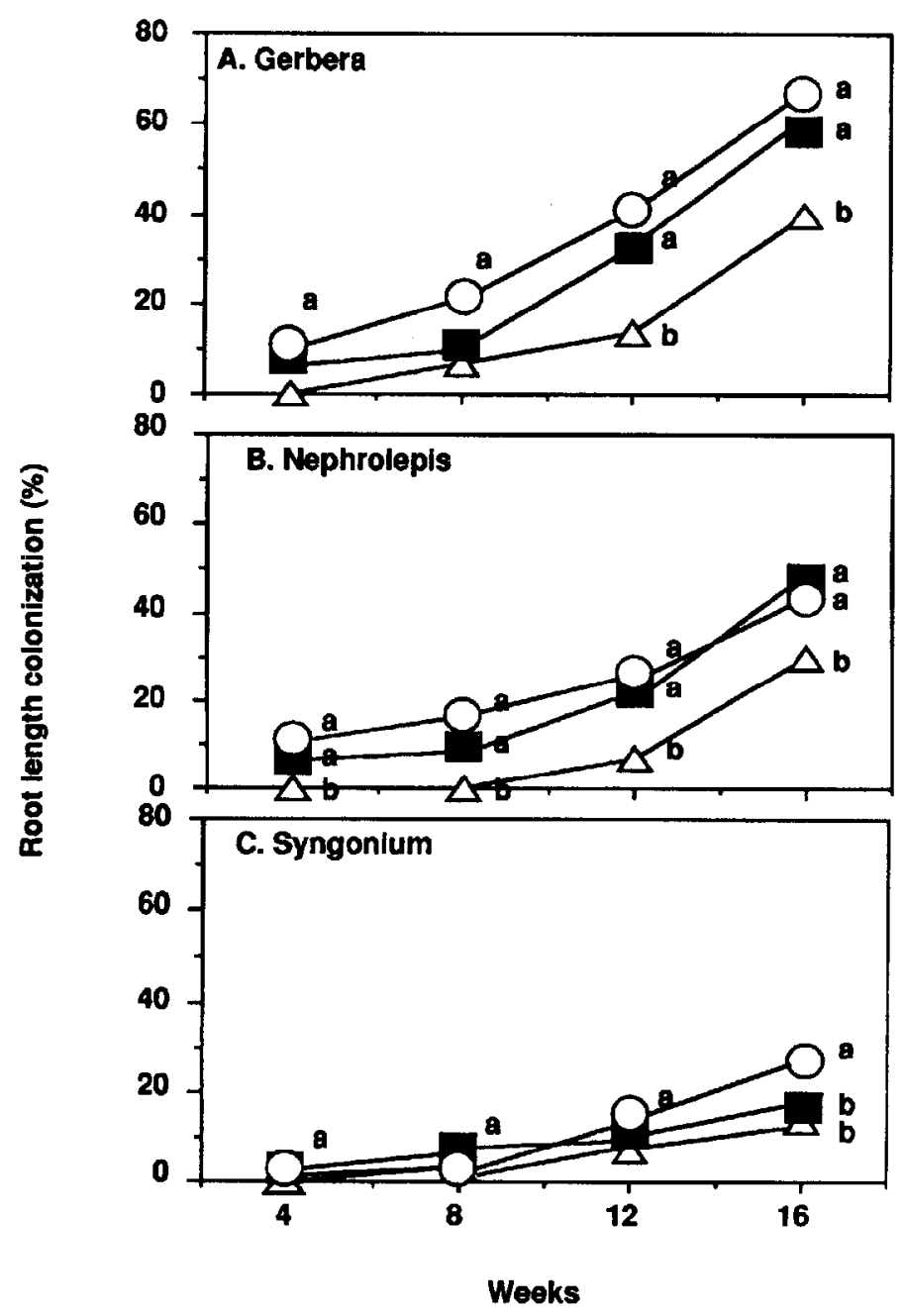

Fig. 2. Effects of different peat-based substrates [substrate $1(\Delta)$, substrate $2(\square)$, substrate 3 (O)] on colonization intensity of Gerbera (A), Nephrolepis (B), and Syngonium (C) with Glomus intraradices at 4, 8, 12, and 16 weeks after inoculation. Mean separation by Duncan multiple range test $(P \leq 0.05)$. 
Table 2. Effects of mycorrhizal fungi and peat-based substrates on plantlet survival ( 4 and 8 weeks after transplanting).

\begin{tabular}{|c|c|c|c|c|c|c|}
\hline \multirow[b]{3}{*}{ Treatment } & \multicolumn{6}{|c|}{ Survival (\%) } \\
\hline & \multicolumn{2}{|c|}{ Gerbera } & \multicolumn{2}{|c|}{ Nephrolepis } & \multicolumn{2}{|c|}{ Syngonium } \\
\hline & 4 week & 8 week & 4 week & 8 week & 4 week & 8 week \\
\hline \multicolumn{7}{|l|}{ Mycorrhizae } \\
\hline Glomus intraradices & 90.0 & $87.8 \mathrm{a}^{\mathrm{x}}$ & 86.7 & $85.3 \mathrm{a}$ & 92.6 & $90.0 \mathrm{a}$ \\
\hline G. vesiculifrum & 92.7 & $88.9 \mathrm{a}$ & 85.9 & $84.4 \mathrm{a}$ & 94.1 & $92.2 \mathrm{a}$ \\
\hline None & 92.2 & $83.3 \mathrm{~b}$ & 84.4 & $80.7 \mathrm{~b}$ & 93.3 & $91.9 \mathrm{a}$ \\
\hline \multicolumn{7}{|l|}{ Substrate } \\
\hline 1 & 90.0 & $82.6 \mathrm{c}$ & 83.7 & $79.6 \mathrm{c}$ & 90.0 & $87.8 \mathrm{~b}$ \\
\hline 2 & 91.9 & $87.1 \mathrm{~b}$ & 84.4 & $82.6 \mathrm{~b}$ & 92.7 & $92.2 \mathrm{a}$ \\
\hline 3 & 93.3 & $90.4 \mathrm{a}$ & 88.9 & $86.3 \mathrm{a}$ & 93.3 & $91.9 \mathrm{a}$ \\
\hline \multicolumn{7}{|c|}{ Significance } \\
\hline Mycorrhizae (M) & NS & * & NS & * & NS & NS \\
\hline Substrate (S) & NS & $*$ & $*$ & $*$ & NS & $*$ \\
\hline $\mathbf{M} \times \mathbf{S}$ & NS & NS & NS & NS & NS & NS \\
\hline
\end{tabular}

${ }^{\bar{z}}$ alues within columns with the same letter are not significantly different (Duncan multiple range test, $P<0.05$ ).

ss, *Nonsignificant or significant at $P \leq 0.05$, respectively.

from test tubes to artificial substrates. Both mycorrhizal inoculation and substrate influenced plantlet survival, and no interaction was observed between these factors. Differences in survival rates of Gerbera, Nephrolepis, and Syngonium plantlets inoculated and not inoculated with mycorrhizal fungi were not visible until 8 weeks after transplanting into inoculated media (Table 2). At this time, survival rates of inoculated plantlets were increased by $5.4 \%$ and $6.7 \%$, with $G$. intraradices and $G$. vesiculiferum for Gerbera, and were increased by $4.6 \%$ and $5.7 \%$ with $G$. intraradices and $G$. vesiculiferum for Nephrolepis. The improved survival rate of mycorrhizal plants appears related to the extent of VAM colonization. There was no effect on Syngonium survival between VAM inoculated and noninoculated treatments.

Different substrates had a significant effect on the survival of the three species (Table 2). All three species planted in the fibric PBS (substrates 2 and 3) survived better than those planted in fibric-mesic PBS (substrate 1). Among the two fibric PBS, survival was higher in substrate 3 for both Gerbera and Nephrolepis. Substrate 3 had less available water, less available P, and was more aerated. Survival rate of plants in substrate 3 was significantly higher by $9.4 \%$ and $3.7 \%$ than in substrates 1 and 2 for Gerbera and also was significantly higher by $8.4 \%$ and $4.4 \%$ than in substrates 1 and 2 for Nephrolepis.

Effects of mycorrhizal PBS on plantlet growth and flower development. Shoot and root dry weights for both Gerbera and Nephrolepis were evaluated in response to mycorrhizal PBS. Both mycorrhizae and substrate treatments influenced growth of Gerbera and Nephrolepis plantlets, while there was no interaction between these factors after 4, 8, 12, or 16 weeks. The only exception was a significant interaction observed between VAM inoculate and substrate for Nephrolepis root dry weight after 16 weeks.

Shoot dry weights of Gerbera and Nephrolepis were increased significantly by VAM-inoculated treatments (Fig. 3). Gerbera inoculated with Glomus intraradices and G. vesiculiferum had, respectively, a $31.5 \%$ and $25.1 \%$ higher shoot dry weight than the control at week $8,17.0 \%$ and $9.4 \%$ higher at week 12 , and $27.7 \%$ and $18.0 \%$ higher at week 16 . The positive effect of VAM increased with the age of the plantlet and reached the highest absolute value at the end of the experiment.

The root growth of Gerbera and Nephrolepis also was influenced by mycorrhizae inoculation. VAM-inoculated plantlets had higher root dry weights than control plants, except at the first sampling period, where no increase in root dry weight was observed for Gerbera (Fig. 3a), and a slight reduction in root dry weight was observed for Nephrolepis (Fig. 3b).

Type of PBS affected the growth effects recorded. In general, Gerbera and Nephrolepis grew significantly more in substrate 3 than in the other two substrates (Fig. 4). Indeed, shoot dry weight was significantly higher at all sampling dates for the two species with substrate 3 than with substrates 1 or 2 . Moreover, for Nephrolepis plantlets, substrate 3 gave the highest root dry weight of any substrate used in this study (Fig. 4b). For Gerbera, differences in root dry weight between substrate 1 or 2 and substrate 3 was only observed at the end of the experiment (Fig. 4a).

Gerbera productivity was evaluated by the number of flowers, capitulum diameter, stem length, and stem diameter (Table 3). VAM-inoculated Gerbera plants produced larger and more flowers than noninoculated Gerbera. There were no differences be-

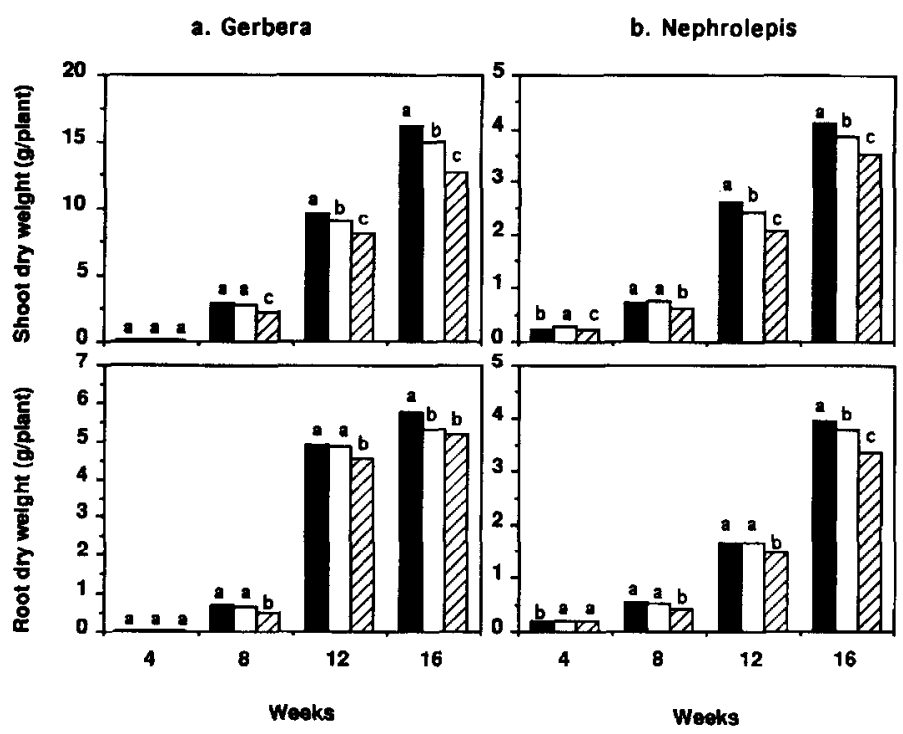

Fig. 3. Shoot and root dry weights of Gerbera (a) and Nephrolepis (b) inoculated with Glomus intraradices (solid), G. vesiculiferum (open), and control (pattern). Mean separation by Duncan multiple range test $(P \leq 0.05)$. 

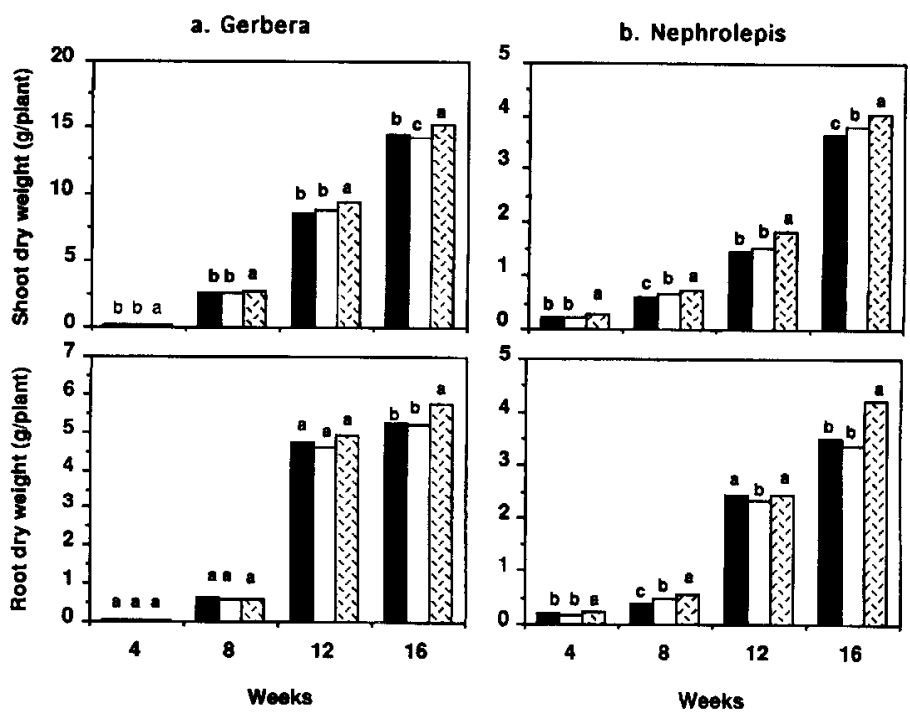

Fig. 4. Shoot and root dry weights of Gerbera (a) and Nephrolepis (b) in different substrates [substrate 1 (solid), substrate 2 (open), and substrate 3 (pattern)] during growth (4 to 16 weeks). Mean separation by Duncan multiple range test $(P \leq 0.05)$.

tween stem length (range 141 to $145 \mathrm{~mm}$ ) and diameter (range 64 to $65 \mathrm{~mm}$ ) related to the treatments. The types of substrates had no significant effect on any of these parameters (data not shown).

\section{Discussion}

This experiment has demonstrated that the VAM fungi $G$. intraradices and $G$. vesiculiferum can establish a symbiotic association with all three tested plant species. The percentage of root colonization for a given fungus varied among the different host plant species. This result confirmed the work of Mosse and Hayman (1973), who reported that plants of many species can be infected by VAM fungi, but the degree of VAM infection and its physiological effects can differ with different host-endophyte combinations. The difference in colonization intensity of VAM fungi might be attributed to the degree of plant receptivity, because the conditions of establishment were the same for the three species. The receptivity of different plant species to VAM fungi may result from the peculiar morphology of in vitro formed roots. Baylis (1972) proposed, in the "root hair hypothesis," that plants are most likely to respond to VAM fungi if their root anatomy allows infection. This author showed that secondary roots and roots with root hairs are more sensitive to VAM infection than tap roots. The root hair hypothesis might well explain why colonization was slower for Syngonium than for the other two species, since Syngonium roots were thick and unbranched with few secondary roots and few root hairs, while in vitro-propagated Gerbera and Nephrolepis had well-developed root systems with abundant root hairs.

In our experiment, no significant differences in root colonization or growth-were observed between $G$. intraradices and $G$. vesiculiferum at 4 weeks. When root colonization rate had increased $\approx 10 \%$ (Fig. 1), significant differences in growth could be observed (Fig. 3), thus suggesting that a relationship exists between root colonization and growth. Plants inoculated with $G$. intraradices had higher shoot and root dry weights than those inoculated with $G$. vesiculiferum, although $G$. vesiculiferum allowed a higher colonization rate than $G$. intraradices did. The results thus indicate that there is not always a strict relation between colonization rate and growth response of host plants. Mosse and Hayman (1973) reported that the most infective endophytes are not necessarily the most effective. VAM efficiency possibly is affected by differences in their symbiotic structures (e.g., arbuscules or vesicles), which could influence the nutrient exchange processes (Hayman, 1983).

The PBS composed of $75 \%$ peat and fertilized with a low level of available $\mathrm{P}$ did not inhibit mycorrhizal colonization. However, different types of the PBS, characterized on the basis of their porosity, significantly influenced symbiont establishment. The ideal substrate for mycorrhizal infection should provide an adequate and balanced water supply, and an abundant oxygen supply for capillary root growth. Comparing the three substrates used in this study, fibric PBS (substrates 2 and 3) was more aerated than the fibric-mesic PBS (substrate 1) (Table 1). Substrate 3, which had good aeration, more available water, and increased mycorrhizal fungi infection activity, stimulated shoot and root growth and improved plantlet survival. The lower colonization intensity for all species grown in substrate 1 can be explained by its high density and poor aeration. This substrate did not allow proper development of new secondary roots and root hairs normally associated with mycorrhizal fungi. Other studies also have shown that high aeration in a substrate is more suitable for root respiration and mycorrhizal fungus activity (Saif, 1981), and poor aeration may be a limiting factor for VAM fungus colonization and may result in low survival of plantlets (Ponton et al., 1990; Saif, 1981, 1984). Our results confirm these observations. Substrates having a fine texture, and normally used for seed germination, are not necessarily well suited for in vitro plantlet acclimatization and further growth in a greenhouse.

Normally, "acclimatization" lasts $\approx 4$ weeks after transferring plantlets from test tubes to a greenhouse. However, VAM infection did not happen in the first 4 weeks following inoculation under our experimental conditions, despite the observation made by Piché and Peterson (1987) that infection, development, and penetration of hyphae and arbuscule and vesicle formation of Glomus monosporum took only 5 to 8 days for leek seedlings, and 8 to 15 days for cotton (Gossypium hirsutum L.), onion (Allium cepa L.), and pepper (Capsicum annuum L.) seedlings (Afek et al., 1990). Thus, VAM fungi apparently do not affect survival during acclimatization. This fact is most probably the result of delayed colonization and symbiosis, which had not yet formed at week 4 .

The lag phase of mycorrhizal colonization probably can be attributed to two main causes. First, root morphology and anatomy of tissue-cultured plants are different from that of seedlings (Pierik, 1987) and probably not amenable to colonization by VAM. Colonization can occur only when new roots are initiated. Second, culture conditions maintained during acclimatization may be unfavorable to VAM colonization. It is well recognized that micropropagated plantlets should be maintained in soil near moisture saturation for the first 2 to 4 weeks after transfer from test tubes

Table 3. Effect of VAM fungi Glomus intraradices and G. vesiculiferum on productivity characteristics of Gerbera 'Terra Mix'.

\begin{tabular}{lcc}
\hline \hline Treatment & $\begin{array}{c}\text { Capitulum } \\
\text { diam } \\
(\mathrm{cm})\end{array}$ & $\begin{array}{c}\text { Flowers } \\
\text { per plant }\end{array}$ \\
\hline G. intraradices & $10.4 \mathrm{a}^{\mathrm{z}}$ & $6.2 \mathrm{a}$ \\
G. vesiculiferum & $10.3 \mathrm{a}$ & $5.2 \mathrm{~b}$ \\
Control & $9.5 \mathrm{~b}$ & $4.4 \mathrm{c}$
\end{tabular}

${ }^{\mathrm{X}}$ Mean separation within columns by Duncan multiple range test, $P \leq$ 0.05 ). 
to soil. Under water saturation, soil $\mathrm{O}_{2}$, diffusion is limited. Low $\mathrm{O}_{2}$ concentration can severely inhibit VAM spore germination and root colonization (Saif, 1981), which may explain why substrate 1 (denser and with less macroporosity than the others) was also the substrate with the lowest percentage of root colonization. Moreover, Reid (1978) reported that moisture saturation in soil reduced VAM colonization by $50 \%$. Our results reveal that to have a positive effect from VAM inoculation during acclimatization, substrate moisture conditions must be controlled precisely.

\section{Literature Cited}

Afek, U., E. Rinaldelli, J.A. Menge, E.L.V. Johnson, and E. Pond. 1990. Mycorrhizal species, root age, and position of mycorrhizal inoculum influence colonization of cotton, onion, and pepper seedling. J. Amer. Soc. Hort. Sci. 115:938-940.

Ames, R.E., C.P.P. Reid, and L.K. Porter. 1983. Hyphal uptake and transfer of nitrogen from two ${ }^{15} \mathrm{~N}$-labelled source by Glomus mosseae, a VAM fungus. New Phytol. 95:381-396.

Augé, R.M., K.A. Schekel, and R.L. Wample. 1986. Osmotic adjustment in leaves of VA mycorrhizal and non-mycorrhizal rose plants in response to drought stress. Plant Physiol. 82:765-770.

Baylis, G.T.S. 1972. Fungi, phosphorus, and the evolution of root systems. Search 3:257-258.

Biermann, B. and R.G. Linderman. 1983. Increased geranium growth using pre-transplant inoculation with a mycorrhizal fungus. J. Amer. Soc. Hort. Sci. 108:972-976.

Bolgiano, N.C., G.R. Saif, and D.D. Warncke. 1983. Mycorrhizal infection and growth of onion in the field in relation to phosphorus and water availability. J. Amer. Soc. Hort. Sci. 108:819-825.

Caron, M. and S. Parent. 1987. The influence of mycorrhizal fungi on carrizo citrange experimental peat-based mix, p. 289-294. In: D.M. Sylvia, L.L. Hung, and J.H. Graham (eds.). Proc. 7th North Amer. Conf. Mycorrhizae, Gainesville, Fla.

Castle, W.S. and J.J. Ferguson. 1982. Current status of greenhouse and container production of citrus nursery trees in Florida. Proc. Fla. State Hort. Soc. 95:42-46.

Chu, I.Y.E. and S.L. Kurtz. 1990. Commercialization of plant micropropagation, p. 126-158. In: P.V. Ammirato, D.A. Evans, W.R. Sharp, and Y.P.S. Bajaj (eds.). Handbook of plant cell culture. vol. 5. McGraw-Hill, New York.

Crews, C.E. and C.R. Johnson. 1978. Benefits of mycorrhizae on growth and development of three woody ornamentals. HortScience. 13:429-430.

Dehne, H.W. 1982. Interaction between VAM fungi and plant pathogens. Phytopathology. 72:1115-1119.

Desjardins, Y., A. Gosselin, and S. Yelle. 1987. Acclimatization of ex vitro strawberry plantlets in $\mathrm{CO}_{2}$ enriched environments and supplementary lighting. J. Amer. Soc. Hort. Sci. 112:846-851.

Desjardins, Y., A. Gosselin., and M. Lamarre. 1990. Growth of transplants and in vitro-cultured clones of asparagus in response to $\mathrm{CO}_{2}$ enrichment and supplemental lighting. J. Amer. Soc. Hort. Sci. 115:364-368.

Donnelly, D.J., W.E. Vidaver, and K.Y. Lee. 1985. The anatomy of tissue cultured red raspberry prior to and after transfer to soil. Plant Cell Tissue Organ Cult. 4:43-50.

Giovannetti, M. and B. Mosse. 1980. An evaluation of techniques for measuring VAM infection in roots. New Phytol. 84:489-500.

Granger, R.L., C. Plenchette, and J.A. Fortin. 1982. Effect of VAM fungus (Glomus epigaeum) on the growth and leaf mineral content of two apple clones propagated in vitro. Can. J. Plant Sci. 61:551-555.

Gramam, J.H. and L.W. Timmer. 1984. Vesicular-arbuscular mycorrhizae development and growth response of rough lemon in soil and soiless media: Effect of phosphorus source. J. Amer. Soc. Hort. Sci. 109:118-121.

Hayman, D.S. 1983. The physiology of VA endomycorrhizal symbiosis. Can. J. Bot. 61:944-963.

Hewitt, E.J. 1966. Sand and water culture methods used in the study of plant nutrition. Comwlth. Agr. Bur. Tech. Commun. 22.

Lee, N. and H.Y. Wetzstein. 1988. Quantum flux density effects on the anatomy and surface morphology of in vitro- and in vivo-developed sweetgum leaves. J. Amer. Soc. Hort. Sci. 113:167-171.

Menge, J.A. 1983. Utilization of vesicular-arbuscular mycorrhizal fungi in agriculture. Can. J. Bot. 61:1015-1024.

Menge, J.A., R.E. Davis, E.L.V. Johnson, and G.A. Zentmeyer. 1978. Mycorrhizal fungi increase growth and reduce transplant injury in avocado. Calif. Agr.. 32:6-10.

Mosse, B. 1973. Plant growth responses to vesicular-arbuscular mycorrhizae: IV. In soil given additional phosphorus. New Phytol. 72:127-136.

Mosse, B. and D.S. Hayman. 1973. Advances in the study of vesiculararbuscular mycorrhizae. Annu. Rev. Phytopathol. 11:171-196.

Murashige, T. and F. Skoog. 1962. A revised medium for rapid growth and bio-assays with tobacco tissue cultures. Physiol. Plant. 15:473-497.

Phillips, J.M. and D.S. Hayman. 1970. Improved procedures for clearing roots and staining parasitic and vesicular-arbuscular mycorrhizal fungi for rapid assessment of infection. Trans. Brit. Mycol. Soc. 55:158-162.

Piché, Y. and R.L. Peterson. 1987. Early events in root colonization by mycorrhizal fungi, p.179-180. In: R. Molina (ed.). Proc. 6th North Amer. Conf. Mycorrhizae, Bend, Ore.

Pierik, R.L.M. 1987. In vitro culture of high plants as a tool in the propagation of horticultural crops. Acta Hort. 226:25-40.

Plenchette, C., V. Furlan, and A.J. Fortin. 1982. Effects of different endomycorrhizal fungi on five host plants growth on the calcined montmorillonite clay. J. Amer. Soc. Hort. Sci. 107:535-538.

Ponton, F., Y. Piché. S. Parent, and M. Caron. 1990; The use of vesiculararbuscular mycorrhizal in Boston fern production: I. Effects of peatbased mixes. HortScience 25:183-189.

Reid, C.P.P. 1978. Mycorrhizae and water stress, p. 392-408. In: A. Riedacker and J. Gagnaire-Michard (eds.). Root physiology and symbiosis. Proc. IUFRO Symp., Nancy, France.

Saif, S.R. 1981. The influence of soil aeration on the efficiency of vesicular-arbuscular mycorrhizas: I. Effect of soil oxygen on the growth and mineral uptake of Eupatorium odoratum L. inoculated with Glomus macrocarpus. New Phytol. 88:649-659.

Saif, S.R. 1984. The influence of soil aeration on the efficiency of vesicular-arbuscular mycorrhizae: III. Soil carbon dioxide and growth and mineral uptake in mycorrhizal and non-mycorrhizal plants of Eupatorium odoratum L., Guizotia abyssinica (L.f.) CASS. and Sorghum bicolor (L.) moench. New Phytol. 96:429-435.

SAS Institute. 1982. SAS user's guide. Statistics. SAS Institute, Cary, N.C. Vanderschaeghe, A.M. and P.C. Debergh. 1987. Technical aspects of the control of the relative humidity in tissue culture containers, p. 68-70. In: G. Ducate, M. Jacob, and A. Simeon (eds.). Proc. Symp. Plant Micropropagation in Hort. Ind.: Preparation, Hardening and Acclimatization Processes, Arlon, Belgium.

Warnche, D.D. 1986. Analyzing greenhouse growth media by the saturation extraction method. HortScience. 21:223-225.

Wetzstein, H.Y. and H.Y. Sommer. 1982. Leaf anatomy of tissue-cultured Liquidambar styraciflua (hamamelidaceae) during acclimatization. Amer. J. Bot. 69:1579-1586.

Wetzstein, H.Y. and H.Y. Sommer. 1983. Scanning electron microscopy of in vitro-cultured Liquidambar styraciflua plantlets during acclimatization. J. Amer. Soc. Hort. Sci. 108:475-480. 